\title{
PENGARUH KOMBINASI MEDIA BUNGKIL KELAPA SAWIT DAN DEDAK PADI YANG DIFERMENTASI TERHADAP PRODUKSI MAGGOT BLACK SOLDIER FLY (Hermetia illucens) SEBAGAI SUMBER PROTEIN PAKAN IKAN
}

\section{THE EFFECT OF PALM KERNEL MEAL AND RICE BRAN MEDIA COMBINATION WHICH ARE FERMENTED TO THE PRODUCTION OF BLACK SOLDIER FLY MAGGOT (Hermetia illucens) AS A SOURCE OF FISH FEED PROTEIN}

\author{
Muhammad Arief, Azela Noor Ratika dan Mirni Lamid \\ Fakultas Perikanan dan Kelautan Universitas Airlangga \\ Kampus C Mulyorejo - Surabaya, 60115 Telp. 031-5911451
}

\begin{abstract}
The high feed prices caused the cost of feed matters were higher for fish farmers so that needed alternative matter. High prices are caused by fish feed, fish feed ingredients that are imported include fish meal which is the main raw material source of protein to feed the fish so that the necessary alternative feed ingredients for use of fish meal. Maggot can be used as alternative feed matter because it contains crude protein ranged between $30-40 \%$ but there are some problems in its production. Media for maggot production used palm kernel meal but the media is hard to find outside of the central plam kernel plantation so as to reduce its use carried out by using a combination of rice bran. Rice bran can be easily to get and can be media for maggot production and low nutrient content of the media production maggot can be corrected through the process of fermentation.

This study aims to determine the effect of the combination of media for the production of maggot and find the best combination of media for the production maggot. This research method is to experiment whit Completely Randomized Desing (CRD). The experiment used is $100 \%$ palm kernel meal (A), $75 \%$ palm kernel meal +25 rice bran (B), $50 \%$ palm kernel meal $+50 \%$ rice bran $(\mathrm{C}), 25 \%$ palm kernel meal $+75 \%$ rice bran $(\mathrm{D})$ and $100 \%$ rice bran with each five replications. The parameters observed were severe maggot production. Analysis of the data used is Analysis of Variance (ANOVA) and to determine the best treatment using Duncan's Multiple range test with a confidence interval of 5\%.

The results of this study indicate that the combination of palm kernel meal and rice bran are fermented to give a noticeable effect the production Maggot.

The best combination of palm kernel meal and rice bran to produce the highest Maggot is the use of palm kernel meal $75 \%+25 \%$ rice bran are not significantly different with the use of palm kernel meal $100 \%$. Based on this research result shows that the use of $25 \%$ of rice bran can reduce the use of $100 \%$ palm kernel meal become only $75 \%$ in maggot production.
\end{abstract}

Keywords : Palm kernel meal, rice bran, the production of black soldier fly maggot (Hermetia illucens)

\section{Pendahuluan}

Harga pakan ikan yang semakin mahal menyebabkan biaya yang dikeluarkan oleh pembudidaya ikan semakin besar. Mahalnya harga pakan ikan disebabkan oleh bahan pakan ikan yang masih diimport (Kompas, 2010). Bahan pakan ikan yang masih diimpor antara lain tepung ikan (Nurfadhilah dkk., 2011). Tepung ikan merupakan bahan baku utama sumber protein untuk pakan ikan (Hadadi, 2009b). Salah satu cara untuk mengurangi biaya pakan adalah dengan mencari bahan pakan alternatif (Bidura, 2005). Maggot dapat dimanfaatkan sebagai bahan baku pakan sumber protein (Hadadi, 2009a) oleh sebab itu maggot dapat dijadikan sebagai bahan pakan alternatif pengganti tepung ikan (Hadadi, 2009b).

Maggot merupakan larva dari serangga Black soldier fly (Hermetia illucens) (Fahmi dan Hem, 2007), memiliki kandungan protein kasar cukup tinggi berkisar antara 30-45\%, mengandung asam lemak esensial (linoleat dan linolenat) dan 10 macam asam amino esensial (Hadadi dkk., 2009b). Sepuluh macam kandungan asam amino esensial maggot black soldier fly seperti Arginin (2,24\%), histidine $(1,91 \%)$, leusine $(3,53 \%)$, isoleusin $(1,96 \%)$, lysin $(3,37 \%)$, methionon $(0,86 \%)$, phenylalanin $(2,20 \%)$, threonin $(0,55 \%)$, tryptofan $(0,20 \%)$ dan valin (3,41\%) (Newton et al., 1977). Beberapa faktor yang menentukan keberhasilan 
dalam produksi maggot antara lain kandungan nutrisi media dan kondisi lingkungan. Maggot menyukai kondisi lingkungan yang lembab (Silmina dkk., 2011) dan rendahnya kandungan nutrisi media dapat diperbaiki melalui proses fermentasi (Widjastuti, 2007).

Bungkil kelapa sawit merupakan media produksi maggot (Ardiansyah dkk., 2010) akan tetapi keberadaan bungkil kelapa sawit sulit didapatkan di luar sentral perkebunan kelapa sawit. Setiawibowo dkk. (2009) menyatakan bahwa selain bungkil kelapa sawit media yang dapat digunakan dalam produksi maggot adalah dedak padi. Keberadaan dedak padi mudah diperoleh dibandingkan bungkil kelapa sawit, pada musim panen dedak padi tersedia melimpah dan sering disimpan sebagai pemakaian jangka panjang (Wibisono, 2010). Berdasarkan latar belakang tersebut alasan dilakukan penelitian kombinasi media bungkil kelapa sawit dan dedak padi yang difermentasi adalah untuk mengurangi penggunaan bungkil kelapa sawit dengan melihat pengaruh kombinasi media sehingga diketahui kombinasi terbaik untuk produksi maggot tertinggi.

\section{Metodologi}

Bahan penelitian menggunakan total media produksi maggot sebanyak $20 \mathrm{~kg}(10 \mathrm{~kg}$ bungkil kelapa sawit dan $10 \mathrm{~kg}$ dedak padi) dan telur maggot sebanyak $2 \mathrm{~g}$ didapatkan dari Institut de Recherche pour le Developpement (IRD) dalam Balai Riset Budidaya Ikan Hias (BRBIH) Depok. Telur dikirim menggunakan salah satu jasa pengiriman barang di Indonesia dimana saat pengiriman telur dipilih yang masih berwarna putih bukan yang telah berwarna kekuningan untuk mencegah telur menetas selama perjalanan. Probiotik cair sebagai fermentor didapatkan dari Fakultas Kedokteran Hewan Universitas Airlangga (FKH UNAIR). Nasution (2009) menyatakan Probiotik yang digunakan dalam penelitian ini mengandung mikroba selulolitik (Cellulomonas dan Actinomyces), proteolitik (Bacillus dan Streptomyces) dan amilolitik (Bacillus dan Amilomyces). Peralatan penelitian yang digunakan meliputi bak berdiameter $34 \mathrm{~cm}$ dengan tinggi $20 \mathrm{~cm}$ sebanyak 20 bak dan 2 bak beriameter $47 \mathrm{~cm}$ dan tinggi $27 \mathrm{~cm}$, terpal, saringan, gelas ukur, timbangan digital, timbangan beras, gloves, pelastik packing, kertas label, karet gelang, thermometer suhu ruangan, strimin, penggaris dan sprayer

Rancangan penelitian kombinasi media bungkil kelapa sawit dan dedak padi yang difermentasi menggunakan Rancangan Acak Lengkap (RAL) yang terdiri dari lima perlakuan dan empat ulangan. Adapun perlakuan tersebut masing-masing adalah:

A : Bungkil kelapa sawit 100\% (kontrol)

B : Bungkil kelapa sawit $75 \%+25 \%$ dedak padi

C : Bungkil kelapa sawit 50\% +50\% dedak padi

D : Bungkil kelapa sawit $25 \%+75 \%$ dedak padi

E : Dedak Padi 100\%

A.Fermentasi

Bungkil kelapa sawit dan dedak padi diambil dari tempat penyimpanan, ditimbang dan dimasukkan ke dalam bak sebagai wadah. Siapkan probiotik untuk proses fermentasi. Berdasarkan penelitian pendahuluan dosis probiotik yang sesuai untuk fermentasi bungkil kelapa sawit dan dedak padi adalah $4 \%$ dengan larutan pengencer berupa air aquadest sebanyak $40 \%$ dari berat media. Larutan probiotik kemudian diseprotkan dengan menggunakan sprayer ke media produksi maggot dan diaduk hingga merata kemudian bak ditutup dengan plastik packing yang diikat dengan karet sehingga rapat setelah itu pelastik diberi sedikit lubang. Fermentasi dilakukan secara anaerob fakultatif selama tujuh hari.

B. Produksi maggot

Media produksi maggot yang digunakan seberat $1 \mathrm{~kg}$, setelah proses fermentasi telur maggot dimasukkan ke dalam setiap media dengan berat telur $0.1 \mathrm{~g}$ kemudian permukaan media ditutup dengan terpal agar terjaga kelembapannya. Proses produksi berlangsung selama14 hari setelah itu maggot dapat dipanen dan dicuci hingga bersih kemudian ditimbang berat maggot yang diperoleh. Data yang diperoleh, diolah dengan menggunakan Analysis of Variance (ANOVA) untuk mengetahui apakah terdapat perbedaan antara perlakuan yang diberikan, kemudian dilanjutkan dengan uji Jarak Berganda Duncan (Duncan's Multiple Range Test) dengan tingkat kepercayaan 5\% untuk mengetahui perlakuan yang terbaik

\section{Hasil dan Pembahasan}

Adapun rata-rata hasil produksi maggot disajikan pada Tabel 1. Berdasarkan analisis statistik dengan menggunakan Analisis Varian dapat diketahui bahwa adanya perbedaan nyata hasil produksi maggot $(\mathrm{P}<0.05)$ 
Tabel 1. Rata-rata hasil produksi maggot

\begin{tabular}{|c|c|}
\hline Perlakuan & $\begin{array}{c}\text { Rata-Rata }(\mathrm{g}) \\
\mathrm{X} \pm \mathrm{SD}\end{array}$ \\
\hline A & $86.5550^{\mathrm{ab}} \pm 4.05221$ \\
$\mathrm{~B}$ & $91.6800^{\mathrm{a}} \pm 4.25864$ \\
C & $82.4525^{\mathrm{bc}} \pm 2.78257$ \\
D & $74.8100^{\mathrm{cd}} \pm 6.82630$ \\
E & $69.9375^{\mathrm{d}} \pm 6.59509$ \\
\hline $\mathrm{a}, \mathrm{b}, \mathrm{c}, \mathrm{d}$ & superskrip yang berbeda dalam kolom \\
\multicolumn{2}{|c|}{ yang sama menunjukkan perbedaan } \\
nyata (p<0.05)
\end{tabular}

Berdasarkan hasil Uji Jarak Berganda Duncan (Duncan's Multiple Range Test), diketahui hasil produksi maggot pada perlakuan B tidak berbeda nyata $(\mathrm{P}>0.05)$ dengan perlakuan A tetapi berbeda nyata $(\mathrm{P}<0.05)$ dengan perlakuan $\mathrm{C}, \mathrm{D}$ dan E. Perlakuan A tidak berbeda nyata $(\mathrm{P}>0.05)$ dengan perlakuan $\mathrm{C}$ tetapi berbeda nyata $(\mathrm{P}<0.05)$ dengan perlakuan D dan E. Perlakuan $\mathrm{C}$ tidak berbeda nyata $(\mathrm{P}>0.05)$ dengan perlakuan $\mathrm{D}$ tetapi berbeda nyata $(\mathrm{P}<0.05)$ dengan perlakuan $\mathrm{B}$ dan E. Perlakuan D tidak berbeda nyata $(\mathrm{P}>0.05)$ dengan perlakuan $\mathrm{E}$ tetapi berbeda nyata $(\mathrm{P}<0.05)$ dengan perlakuan A dan B. Perlakuan E berbeda nyata $(\mathrm{P}<0.05)$ dengan perlakuan $\mathrm{A}$, $\mathrm{B}$ dan C. Grafik rata-rata produksi maggot dapat dilihat pada Gambar 1.

\section{Panjang dan Berat Individu Maggot}

Bedasarkan hasil sampel panjang dan berat individu maggot pada perlakuan A menunjukkan berat rata-rata maggot $0.147 \mathrm{~g}$ dengan panjang rata-rata $1.75 \mathrm{~cm}$ dan pada perlakuan B berat rata-rata maggot $0.159 \mathrm{~g}$ dengan panjang rata-rata $1.72 \mathrm{~cm}$. Perlakuan C menunjukkan berat rata-rata maggot $0.136 \mathrm{~g}$ dengan panjang rata-rata $1.66 \mathrm{~cm}$ sedangkan berat rata-rata maggot pada perlakuan D $0.109 \mathrm{~g}$ dengan panjang rata-rata $1.51 \mathrm{~cm}$. Perlakuan E berat rata-rata maggot $0.049 \mathrm{~g}$ degan panjang rata-rata $1.19 \mathrm{~cm}$. Perbedaan morfologi maggot pada setiap perlakuan dapat dilihat pada Gambar 2.

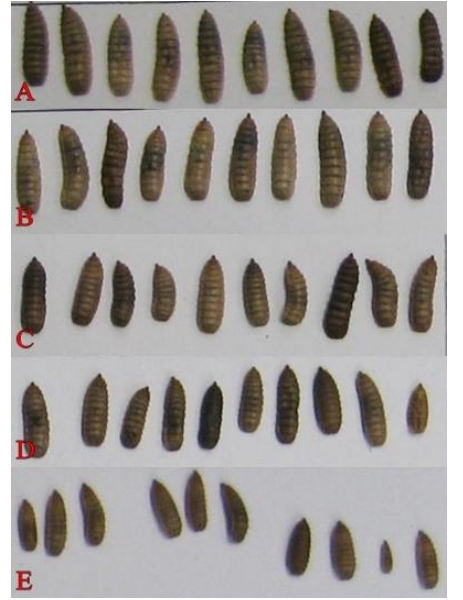

Gambar 2. Perbedaan morfologi maggot pada setiap perlakuan

Suhu Lingkungan

Salah satu pengaruh dalam produksi maggot adalah suhu dimana suhu mempengaruhi waktu penetasan telur black soldier fly. Data suhu lingkungan selama penelitian dapat dilihat pada Lampiran 10 dimana suhu lingkungannya berkisar antara 29$32^{\circ} \mathrm{C}$. Pengukuran suhu menggunakan thermometer ruangan

Bungkil kelapa sawit merupakan media produksi maggot (Ardiansyah dkk., 2010) dimana hasil produksi dari $3 \mathrm{~kg}$ bungkil kelapa sawit fermentasi dapat menghasilkan $1 \mathrm{~kg}$ maggot (Adijaya dan Susanti, 2009). Maggot dapat mengubah material organik menjadi berat tubuhnya (Fahmi dan Hem, 2007). Gary (2009) dalam Silmina dkk. (2011) menyatakan bahwa maggot akan mereduksi nutrien yang terdapat di media 50-70\%. Ng et al (2003) dalam Hadadi dkk. (2009a) menyatakan bahwa maggot mempunyai beberapa enzim pencernaan seperti enzim proteolytic, enzim fibrolytic atau enzim degradasi karbohidrat. Enzim tersebut terdapat dalam tubuh maggot sehingga mampu mencerna bahan organik dengan kandungan serat tinggi yang kemudian diubah menjadi bahan protein

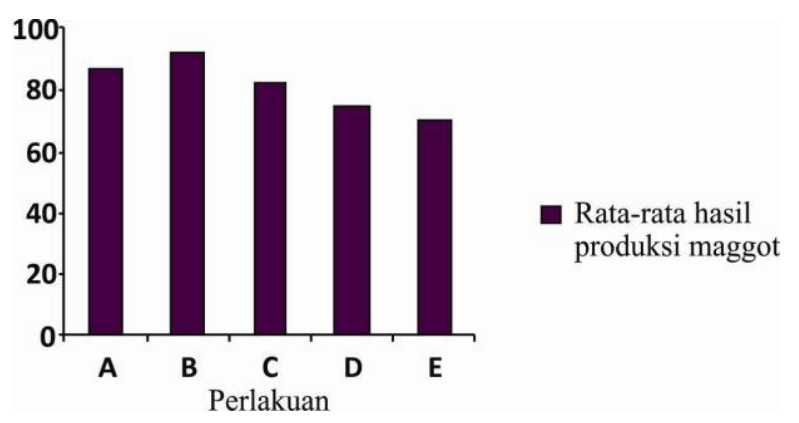

Gambar 1. Grafik rata-rata hasil produksi maggot 
(Hadadi dkk., 2009a)

Berdasarkan hasil penelitian produksi maggot yang disajikan pada Tabel 1 dan hasil Analisis Varian menunjukkan bahwa kombinasi media bungkil kelapa sawit dan dedak padi yang difermentasi memberikan pengaruh yang berbeda nyata terhadap hasil produksi maggot. Perlakuan B merupakan produksi maggot tertinggi dimana perlakuan B menunjukkan tidak adanya perbedaan yang nyata dengan perlakuan A (kontrol) tetapi berbeda nyata dengan perlakuan $\mathrm{C}, \mathrm{D}$ dan $\mathrm{E}$. Diduga kandungan nutrisi media perlakuan B merupakan kandungan nutrisi yang optimum bagi peroduksi maggot.

Setiawibowo dkk. (2011) menyatakan bahwa kandungan nutrisi yang optimum sangat penting untuk mendapatkan nilai produksi maggot yang tinggi disertai kualitas berat maggot yang baik. Hal ini dapat dilihat dari hasil rata-rata produksi maggot dan berat ratarata individu maggot pada perlakuan B (91.6800 g dan $0.159 \mathrm{~g})$, perlakuan A $(86.5550 \mathrm{~g}$ dan $0.147 \mathrm{~g})$, perlakuan C (82.4525 g dan $0.136 \mathrm{~g})$, perlakuan D (74.8100 g dan $0.109 \mathrm{~g})$ dan perlakuan E (69.9375 g dan $0.049 \mathrm{~g}$ ).

Berdasarkan hasil analisis proksimat media produksi maggot menunjukkan bahwa kandungan protein kasar perlakuan A (18.1022\%), lemak kasar (3.4351\%), serat kasar $(27.4893 \%)$ sedangkan kandungan protein kasar perlakuan B (13.9919\%), lemak kasar (3.4527\%), serat kasar (29.5851\%). Bila dilihat dari kandungan protein kasar pada perlakuan A (kontrol) masih lebih tinggi bila dibandingkan perlakuan B yang menghasilkan produksi maggot tertinggi. Keberhasilan produksi maggot tidak hanya dapat dilihat dari kandungan protein kasar yang tinggi. Silmina dkk. (2011) menyatakan bahwa nilai protein yang tinggi pada media tidak menjamin kebutuhan nutrisi bagi pertumbuhan maggot. Hal ini sesuai dengan yang dinyatakan oleh Soetanto (2002) bahwa dalam memenuhi kebutuhan nutrisi tubuh membutuhkan air, protein, lemak, serat kasar dan energi. Air berperan dalam proses pencernaan (hidrolisis protein, karbohidrat maupun lemak), proses penyerapan zat gizi, proses transport metabolit di dalam tubuh serta proses eksresi sisa metabolit keluar tubuh. Energi dalam pakan umumnya berasal dari karbohidrat dan lemak. Zat-zat pakan yang dapat menjadi sumber energi yaitu protein, lemak, serat kasar dan BETN. Kekurangan energi dapat mengakibatkan terhambatnya penambahan bobot tubuh (Haryanti, 2009).

Kandungan serat kasar yang cukup tinggi pada perlakuan $\mathrm{B}$ bila dibandingkan dengan perlakuan A dalam tubuh maggot akan mengalami perombakan. Maggot mempunyai beberapa enzim pencernaan seperti enzim proteolytic, enzim fibrolytic atau enzim degradasi karbohidrat $\mathrm{Ng}$ et al (2003) dalam Hadadi dkk. (2009a). Kim et al (2011) juga menyatakan bahwa dalam saluran pencernaan maggot terdapat amilase, lipase, dan aktivitas protease. Enzim tersebut mampu mencerna bahan organik dengan kandungan serat tinggi (Hadadi dkk., 2009a). Hasil penguraian karbohidrat akan diubah menjadi monosakarida (glukosa, galaktosa, fruktosa) dan diserap oleh tubuh. Apabila jumlah karbohidrat yang dimakan melebihi kebutuhan tubuh, sebagian besar akan disimpan di dalam otot dan selebihnya sebagai glikogen dalam hati. Penimbunan glikogen berlebih, karbohidrat akan diubah menjadi lemak dan disimpan dalam jaringan lemak (Hutagalung, 2004). Lemak di dalam tubuh maggot terletak disekitar saluran pencernaan dan organ-organ lain dimana kandungannya $65 \%$ dari berat total tubuh maggot (Suswara, 2010).

\section{Kesimpulan}

Berdasarkan hasil penelitian yang diperoleh pada penelitian kombinasi media produksi maggot, maka dapat ditarik kesimpulan sebagai berikut : Kombinasi media bungkil kelapa sawit dan dedak padi yang difermentasi memberikan pengaruh yang berbeda nyata terhadap hasil produksi maggot. Kombinasi terbaik media bungkil kelapa sawit dan dedak padi yang difermentasi untuk menghasilkan produksi maggot tertinggi adalah penggunaan bungkil kelapa sawit $75 \%$ + dedak padi $25 \%$ yang tidak berbeda nyata dengan bungkil kelapa sawit 100\% (kontrol).

Berdasarkan hasil penelitian ini menunjukkan penggunaan dedak padi $25 \%$ dapat menggurangi penggunaan bungkil kelapa sawit $100 \%$ hingga menjjadi $75 \%$ dalam produksi maggot.

\section{Daftar Pustaka}

Adijaya. D dan T. Susanti. 2009. Maggot Pakan Hebat. Trubus. 20 Juli 2009 : 6.

Ardiansyah, Muh., F. Amri, N. I. Sari, N. Faidah, Nasni. 2010. Maggot (Hermetia illucens) sebagai Pakan Alternatif untuk Mencerahkan Warna Ikan Koi (Cyprinus carpio. L). Politeknik Pertanian Negeri. Pangkajene dan Kepulauan. Pangkep. 23 hal

Bidura, I. G. N. G. 2005. Penyediaan Pakan Unggas. Buku Ajar Jurusan Nutrisi dan Makanan Ternak Fakultas Peternakan 
Universitas Udayana.Dempasar. hal 1056.

Fahmi. M. R dan S. Hem. 2007. Potensi Maggot sebagai Salah Satu Sumber Protein Pakan Ikan. Loka Riset Budidaya Air Tawar Depok dan IRD (Institut de Recherche Pour le Developpement) Perancis. 7 hal

Hadadi, A., Herry, K. T Wibowo, E. Pramono, A. Surahman, dan E. Ridwan. 2009a. Aplikasi Pemberian Maggot Sebagai Sumber Protein Dalam Pakan Ikan Lele Sangkuriang (Clarias sp.) dan Gurame (Osphronemus gouramy Lac.). Laporan Tinjauan Hasil Tahun 2008 Balai Besar Pengembangan Budidaya Air Tawar Sukabumi. hal $175-181$.

Hadadi, A., Herry, Setyorini, dan E. Ridwan. 2009b. Produksi Massal Maggot Untuk Pakan Ikan. Jurnal Budidaya Air Tawar Balai Besar Pengembangan Budidaya Air Tawar Sukabumi. hal. 250 - 468.

Haryanti,N. W. 2009. Kualitas Pakan dan Kecukupan Nutrisi Sapi Simental Di Peternakan Mitra Tani Andini, Kelurahan Gunung Pati, Kota Semarang. Fakultas Peternakan. Universitas Diponogoro. 78 hal

Hutagalung, H. 2004. Karbohidrat. Fakultas Kedokteran. Universitas Sumatra Utara. 11 September 2011. 13 hal

Kompas. 2010. Pajak Perikanan: Daya saing Produk Ikan Terancam. Kompas, 5 April $2010: 19$

Kim, W., S. Bae, K. Park, S. Lee, Y. Choi, S. Han and Y. Koh. 2011. Biochemicl Characterization of Digestive Enzym in The Black Soldier Fly,Hermetia il lucens (Diptera: Stratiomyidae). Journal of Asia-pacfic entomology 14 (2011) : 1114

Nasution, E. R. J. 2009. Pemanfaatan Tepung Isi Rumen Yang Dfermentasi Dengan Probiotik Sebagai Subsitusi Bekatul Terhadap Performan Ayam Pedaging. Fakultas Kedokteran Hewan. Universitas Airlangga. 38 hal
Newton, G. L., C. V. Booram, R. W. Barker, and O. M. Hale. 1977. Dried Hermetia illucens larvae meal as a supplement for swine. J. Anim. Sci. 44: 395-399.

Nurfadhilah, Z. Agustina dan C. S. Bani. 2011. Fermentasi: Teknologi Sederhana Pengolahan Bahan Baku Lokal dalam Pembuatan Pakan Ikan. PKM Gagasan Tertulis. 3 Maret 2011. Institut Pertanian Bogor. Bogor. 17 hal.

Setiawibowo, D. A., D. A. Sipayung dan H. G. P. Putra. 2009. Pengaruh Beberapa Media Terhadap Pertumbuhan Populasi Maggot (Hermetia illucens). http://iirc. ipb. ac.id. 17 September 2010. 9 pp

Silmina, D., G. Edriani dan M. Putri. 2011. Efektifitas Berbagai Media Budidaya terhadap Pertumbuhan Maggot Hermetia illucens. Institut Pertanian Bog or. Bogor. 7 hal.

Soetanto, H. 2002. Kebutuhan Gizi Ternak Ruminansia Menurut Stadia Fisiologisnya. Reorientasi Formulator Pakan Ternak-Dispet Jatim. Juli 2002. Malang. 19 hal.

Suswara, E. 2010. Materi Kuliah Entomologi. http://abdullah-kuasaillahi.blogspot.com. 6 September 2011. 7 pp

Wibisono A.W. 2010. Analisa Dedak Padi Untuk Pakan Sapi. http://duniasapi.com. 6 Januari 2011. 2 pp

Widjastuti, T., Abun, W. Tanwiriyah, I. Y. Asmara 2007. Pengolahan Bungkil Inti Sawit Melalui Fermentas Oleh Jamur Marasmius sp. Guna Menunjang Bahan Pakan Alternatif Untuk Ramsum Ayam Broiler. http://pustaka.unpad.ac.id. 2 Desember 2010. 90 pp 